\title{
The Role of Non-Timber Forest Products (NTFPs) in Tribal Economy of Jharkhand, India
}

\author{
M.A. Islam ${ }^{*}$ and S.M. S. Quli ${ }^{2}$ \\ ${ }^{1}$ Faculty of Forestry, Sher-e-Kashmir University of Agricultural Sciences and Technology of \\ Kashmir, Benhama, Ganderbal-191201 (J\&K), India \\ ${ }^{2}$ Faculty of Forestry, Birsa Agricultural University, Kanke, Ranchi-834006 (Jharkhand), India \\ *Corresponding author
}

\begin{tabular}{|c|c|}
\hline & \\
\hline & \multirow{11}{*}{ 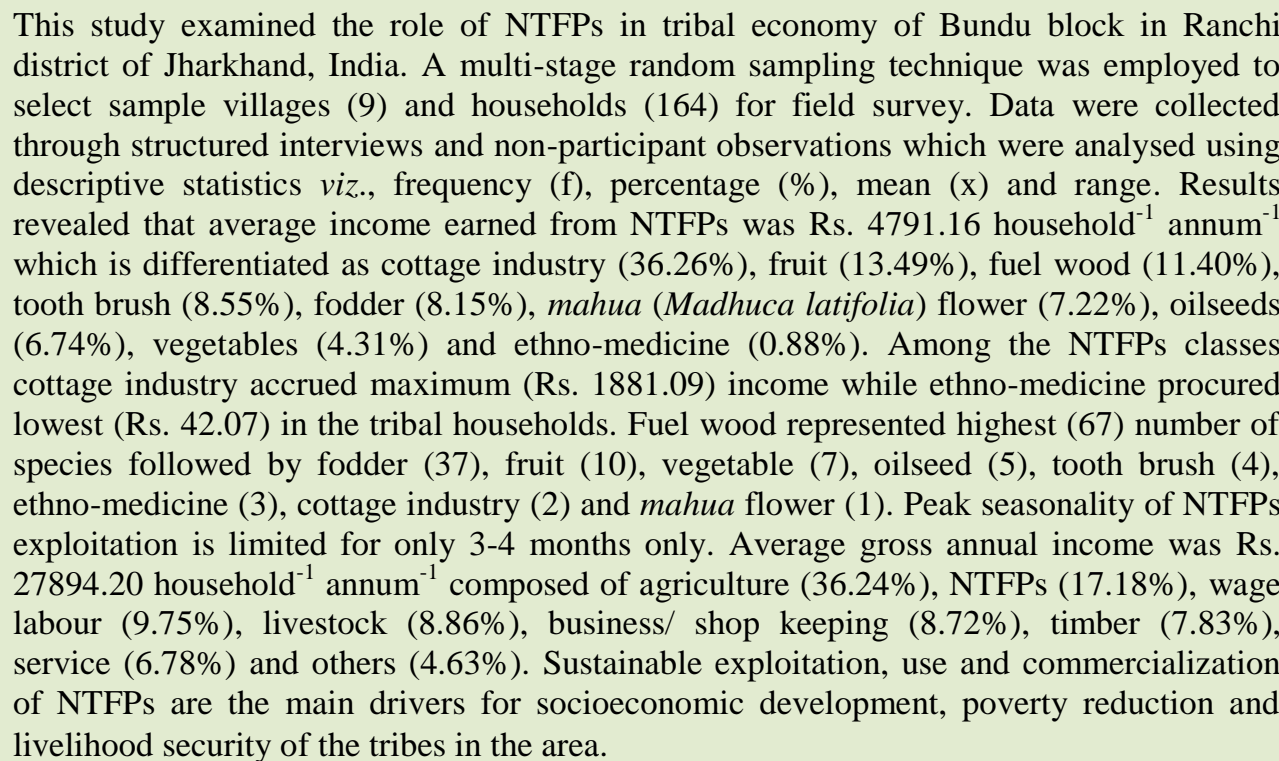 } \\
\hline & \\
\hline & \\
\hline Livelihood, & \\
\hline & \\
\hline & \\
\hline Article Info & \\
\hline & \\
\hline & \\
\hline & \\
\hline & \\
\hline
\end{tabular}

\section{Introduction}

Globally, more than two billion people are dwelling in forests, depending on forest resources for subsistence, income and livelihood security (Ahenkan and Boon, 2011). NTFPs are considered to be vital for sustaining rural livelihoods, reducing rural poverty, biodiversity conservation and facilitating rural economic growth (Maske $e t$ al., 2011). The World Health Organization estimated that about $80 \%$ of the population of the developing countries uses NTFPs to meet their health and nutritional needs (Olaniyi et al., 2013). Additionally, several opportunities for improved rural development and standard of living are linked to NTFPs (Ajake and Enang, 2012; Islam et al., 2013). NTFPs are in daily use throughout the tropics, commonly providing resources crucial to people where no other social security is provided by the state (Bharathkumar et al., 2011). NTFPs 
greatly influence the socioeconomic development in rural communities; enhance the quality of environment by influencing the life supporting system and play leading role in culture and civilization (Ghosal, 2011). The forest fringe communities use NTFPs for diverse purposes like medicinal, edible fruits, vegetables, oilseeds, ornamental, cottage industry, fuel wood, fodder, dyes, tannins, narcotic, drinks, housing materials, agricultural implements, weapons, fibers, furniture items, packing materials, matches, sports goods, lac, floss etc. (Saha and Sundriyal, 2012). NTFPs collection and sale is often viewed as a marginal activity, though in reality the trade of these products provides significant economic benefits to many rural households and communities (Chamberlain et al., 2000). NTFPs play prominent roles in improving living standards through variant socioeconomic services such as source of food to households, income generation potentials, provision of safety-net or insurance in times of a tragedy, preservation of cultural heritage and spirituality and financial saving by households (Shackleton and Pandey, 2014).

India has about 16000 plant species; of which 3000 yield NTFPs providing 40\% of forest revenues and $55 \%$ forest based employment (Shit and Pati, 2012). According to World Resource Institute, over 500 million people in India are dependent on NTFPs for their subsistence and cash income (Sarmah and Arunachalam, 2011). The income from sale of the NTFPs for households living in and around forest constitutes 40 to $60 \%$ of their total income (Nayak et al., 2014). NTFPs are not only a source of subsistence income for millions of poor households but also provide employment to rural poor in the form of direct employment, self-employment and secondary employment (Prasad and Siddiqui, 2006). Livelihood contribution of NTFPs to rural households is uneven because it depends on diversity and availability of NTFPs, proximity to forest, family labour, marketability of the resources, extent of rights and concessions conferred etc. (Melaku et al., 2014). NTFPs based livelihood systems vary considerably between different regions and among the various ethnic groups, depending on ecological, historical, cultural, geo-climatic factors in India (Tewari, 2014).

Tribal communities inhabiting in and around the northern tropical dry deciduous forest of Bundu block in Ranchi district mainly depend on NTFPs for their subsistence livelihood and substantial income earnings (Islam et al., 2015). Fuel, fodder, fruits, seeds, vegetables, medicines, fertilizer, fibre, floss, oilseed, ornaments etc. are the main NTFPs extracted by the tribes. The NTFPs play a central role in the socioeconomic, cultural and political systems of tribal societies and the entire lives and livelihoods of these people revolve around forests and forestry (Bedia, 2014). Modernization and unethical development in the block has created a marked decrease in NTFPs which is severely affecting the livelihoods of the forest fringe communities (Gharai and Chakrabarti, 2009). Understanding the livelihood dependency on NTFPs among tribal communities in rural areas can help policy makers design and implement effective strategies for poverty alleviation, livelihood improvement, conservation and sustainable NTFPs use. With this background the current research is contemplated to quantify and analyze the diversity of NTFPs and its livelihood contribution to the tribal households of sample villages in Bundu block of Ranchi district in Jharkhand, India.

\section{Materials and Methods}

\section{The study area}

The study was conducted in Bundu block (Fig. 1.) of Ranchi district in Jharkhand situated at $23^{0} 11^{\prime}-23^{0} 18^{\prime}$ North latitude and 
$85^{0} 35^{\prime}-85^{0} 58^{\prime}$ East longitude at an altitude of 337 meters above MSL. Total geographical area of the block is 25097 ha which is differentiated as: un-irrigated cultivable land $(69.25 \%)$, forest $(17.44 \%)$, irrigated cultivable land $(8.41 \%)$, culturable wasteland (3.59\%), unculturable wasteland (1.29\%) and non-agricultural use $(0.02 \%)$. The forest resource is predominantly covered by northern tropical dry deciduous forest (5B/C2) (Champion and Seth, 1968) falling under Bundu Range of Khunti Forest Division. The tropical climate is divisible into three different seasons, viz., rainy (mid JuneSeptember), winter (October-February) and summer (March-mid June). The average annual normal precipitation is $1413.60 \mathrm{~mm}$, the mean minimum temperature is $24^{\circ} \mathrm{C}$ and mean maximum temperature is $37.2^{\circ} \mathrm{C}$. According to the Census of India (2011), the total population of the block is 62509 (31624 males and 30885 females) living in 11495 households of 88 villages. The literates in the block are 23572 (16084 males and 7488 females) accounting $44.02 \%$ of the total population (Anon., 2009). Of the total population, $60.74 \%$ are ST (Munda, Oraon and Lohara), $4.76 \%$ are SC and rest $34.50 \%$ belongs to other social groups (Anon., 2009). The population density, family size and sex ratio are $249.07 / \mathrm{km}^{2}, 5.44$ and 978 female/ 1000 male, respectively. Agriculture and NTFPs collection are the main sources of subsistence livelihood.

\section{Sample selection}

Bundu block of Ranchi district was purposely chosen for the current study as a majority of the tribal households in the block are dependent on NTFPs considerably for livelihood security. A multi-stage random sampling technique (Ray and Mondol, 2004) was used for selection of villages and households. Nine (10\%) sample villages viz., Korda, Jojoda, Husirhatu, Banaburu,
Nehalgara, Ghagrabera, Hesapiri, Roredih and Kuchidih were selected randomly from Bundu block. The sample was consisted of 164 (20\%) randomly selected households from the sample villages comprising all categories of the land holders. The interviews were conducted with household heads or eldest members.

\section{Data collection and analysis}

Data on NTFPs exploitation by tribal households were collected through personal interviews of the respondents through a wellstructured pre-tested interview schedule and non-participant observations (Mukherjee, 1993). The parameters included NTFP type, plant part, species name, plant habit, seasonality, usage, collection annum ${ }^{-1}$, consumption annum $^{-1}$, sale rate, sale annum ${ }^{-1}$ and income earned. Monetary values of NTFPs were calculated as per their local market rates. The annual household income consisted of various sources was also recorded. Simple descriptive statistics viz., frequency (f), percentage (\%), mean (x) and range were used for analysis of the data (Snedecor and Cochran, 1967) and the results were displayed through tables and charts.

\section{Results and Discussion}

\section{Exploitation of NTFPs by the tribal households}

The average income earned from NTFPs in the surveyed population was Rs. 4791.16 household $^{-1}$ annum $^{-1}$. The cottage industry fetched highest income per annum (Rs. 1881.09) among tribal households followed by fruit (Rs. 646.21), fuel wood (Rs. 546.34), tooth brush (Rs. 409.75), fodder (Rs. 390.24), mahua (Madhuca latifolia) flower (Rs. 346.09), oilseed (Rs. 322.70), vegetable (Rs. 206.61) and ethno-medicine (Rs. 42.07) (Table 1). Among indigenous use classes, 
maximum (67) number of species were used for fuel wood followed by fodder (37), fruit (10), vegetable (7), oilseed (5), tooth brush (4), ethno-medicine (3), cottage industry (2) and mahua flower (1) (Fig. 2.).

Sal leaf plate making and lac cultivation are the prominent cottage industries of the tribal households contributing a sizeable share in their income. People collect sal leaves, process, stitch raw plates and sell in the local haats (weekly markets) earning sizeable income, however, there is a large demand of machine pressed sal leaf plates in urban areas and has the potential of bringing additional income to the people by value addition through mechanized moulding. Lac cultivation is practiced by the tribal people on all the three host plants viz., palas (Butea monosperma), ber (Zizyphus mauritiana), kusum (Schleichera oleosa) using both rangeeni and kusmi strains of lac insects. Mango (Mangifera indica), jamun (Syzigium cumini), ber (Zizyphus mauritiana), imli (Tamarindus indica), bhelwa (Semecarpus anacardium), kendu (Diospyros melanoxylon), toont (Morus alba), bel (Aegle marmelos), kathal (Artocarpus heterophyllus) and barhar (Artocarpus lakoocha) are the chief edible fruits collected, consumed and sold. These edible fruits are an indispensable source of diet, food, nutrition, health care and livelihood in tribal households. Fuel wood is tribal society's traditional source of energy constituting the mainstay of households cooking and heating energy besides meeting the fuel requirements for cottage industries, community functions, household rituals e.g. marriage, child birth, child christening, death, ancestral worship etc., religious functions namely, worship of God and Goddess, festivals, coercing of evil spirits and witchcraft etc. Collection and sale of tooth brushes of sal (Shorea robusta), karanj (Derris indica), neem (Azadirachta indica) and mahua (Madhuca latifolia) in local as well as urban markets is a common business of tribal children and women fetching good returns.

Livestock production is an important component of tribal economy, which predominantly depends on quality and quantity of fodder availability. Forests in vicinity of the villages not only offer plenty of grazing lands with enough fodder availability for livestock rearing but also provide employment and income opportunities. Dried mahua (Madhuca latifolia) flowers are used for preparation of country liquor which is sold by the tribal women in make-shift shops in local weekly haats and consumed by the people almost in all functions, ceremonies and festivals. Thus, the sale of dried mahua flowers in nearby markets is an important NTFPs based self-employment for the tribal people earning a considerable income. Oilseeds of chironji (Buchanania lanzan), mahua (Madhuca latifolia), kusum (Schleichera oleosa), sal (Madhuca latifolia) and karanj (Derris indica) are collected and sold seasonally in good quantity for extracting oil consumed in cooking, lighting, massage, medicinal or lubrication and the residue oilseed cake is consumed as cattle feed or medicine. Koinar (Bauhinia purpuria) leaf, bamboo (Bambusa arundinacea) corn, kachnar (Bauhinia variegata) flower, phutkal (Ficus glabella) leaf, jirhul (Indigofera arborea) flower, rugra (Lycoperdon spp.) basidiocarp and khukhri (Agaricus compestris) basidiocarp are important vegetables for the local population collected and sold for earnings. Vegetables ripe, unripe, green, dried, cooked or uncooked are consumed by the local people after preparing sauce, pickle, soar, roasted or boiled stuff. Chirayita (Swertia angustifolia), harra (Terminalia chebula) and bahera (Terminalia belerica) are the well-known medicinal items collected, dried and sold by the tribal people in local as well as urban markets. NTFPs 
collected and sold by the tribal people throughout the year in local haats as well as in nearby urban markets which fetches handsome earnings to the vendors. Collection and marketing of NTFPs varies with the types of resources, household consumption, availability and market price and socioeconomic condition of the people (Islam and Quli, 2015). NTFPs play a potent role in the livelihood support of tribal and forest dwellers in terms of subsistence, income and employment generation (Singh and Quli, 2011). The tribal people possess the traditional skill base, have access to the resource base and have supportive government policies on NTFPs management and trade (Bedia, 2014).

NTFPs contribute to livelihoods for the large proportion of poor living in forests of developing countries (Opaluwa et al., 2011). NTFPs based incomes vary across tribal households depending upon the degree of effort expended and contribute significantly to the total household income (Islam et al., 2015). The findings are not unusual and a significant number of studies (Salehi et al., 2010; Opaluwa et al., 2011; Singh and Quli, 2011; Saha and Sundriyal, 2012; Olaniyi et al., 2013; Bedia, 2014; Sharma et al., 2015;
Islam and Quli, 2015; Shrey et al., 2017) across the world have demonstrated the dependency of forest dwellers on NTFPs for both subsistence and cash income.

\section{NTFP based income composition}

Among the NTFPs categories, cottage industry procured maximum $(36.26 \%)$ income followed by fruit (13.49\%), fuel wood $(11.40 \%)$, tooth brush $(8.55 \%)$, fodder (8.15\%), mahua (Madhuca latifolia) flower $(7.22 \%)$, oilseeds $(6.74 \%)$, vegetables $(4.31 \%)$ and ethno-medicine $(0.88 \%)$ (Fig. 3.). Sal leaf plate making and lac cultivation were the major cottage industries contributing maximum share to the NTFPs based annual income. Skillfully stitched Sal leaf plates have local, national as well as global markets due to cheap, disposable, bio-degradable, hygienic and ecological substitute for thermocol and plastic plates, chiefly used locally to serve and pack food in the grocery shops, petty hotels, temples, marriage, festivals, ceremonies etc. and to make offerings to Hindu Gods. Lac cultivation is a subsidiary source of income for a large number of tribal households playing a potent role in their socioeconomy.

Table.1 Household exploitation of NTFPs by the tribal people

\begin{tabular}{|c|c|c|c|c|c|}
\hline NTFPs & $\begin{array}{l}\text { Collection } \\
\left(\mathrm{kg} \mathrm{annum}^{-1}\right)\end{array}$ & $\begin{array}{l}\text { Consumption } \\
\left(\mathrm{kg} \mathrm{annum}^{-1}\right)\end{array}$ & $\begin{array}{l}\text { Marketing } \\
\left(\mathrm{kg} \text { annum }^{-1}\right)\end{array}$ & $\begin{array}{l}\text { Rate } \\
\left(\text { Rs. kg }{ }^{-1}\right)\end{array}$ & $\begin{array}{l}\text { Income } \\
\left.\text { (Rs. annum }^{-1}\right)\end{array}$ \\
\hline Fuel wood & 3759.26 & 3650.00 & 109.26 & 5.00 & 546.34 \\
\hline Fodder & 17300.91 & 17222.86 & 78.04 & 5.00 & 390.24 \\
\hline \multicolumn{6}{|l|}{ Cottage industry } \\
\hline Sal leaf plate & $34176.82^{\Omega}$ & $2469.51^{\Omega}$ & 31707.31 & 0.32 plate $^{-1}$ & 1268.29 \\
\hline Lac & 4.08 & 0.00 & 4.08 & 150.00 & 612.80 \\
\hline \multicolumn{6}{|l|}{ Fruit } \\
\hline Fruits (kg) & 76.42 & 23.87 & 52.54 & $5.00-20.00$ & 627.98 \\
\hline Bel (no.) & $6.99^{\Omega}$ & $0.91^{\Omega}$ & $6.07^{\Omega}$ & $3.00 \Omega^{-1}$ & 18.23 \\
\hline Vegetable & 26.81 & 7.68 & 19.12 & $10.00-25.00$ & 206.61 \\
\hline Oilseeds & 19.63 & 2.10 & 17.53 & $10.00-150.00$ & 322.70 \\
\hline Ethno-medicine & 0.51 & 0.00 & 0.51 & $50.00-140.00$ & 42.07 \\
\hline Tooth brush & $64.97^{\S}$ & $24.00^{\S}$ & $40.97^{\S}$ & $10.00 \S^{-1}$ & 409.75 \\
\hline Маһиа flower & 40.64 & 6.03 & 40.60 & 10.00 & 346.09 \\
\hline Total & - & - & - & - & 4791.16 \\
\hline
\end{tabular}

Note: $\Omega=$ pieces; $\S=$ bundles 
Fig.1 Location map of the study area

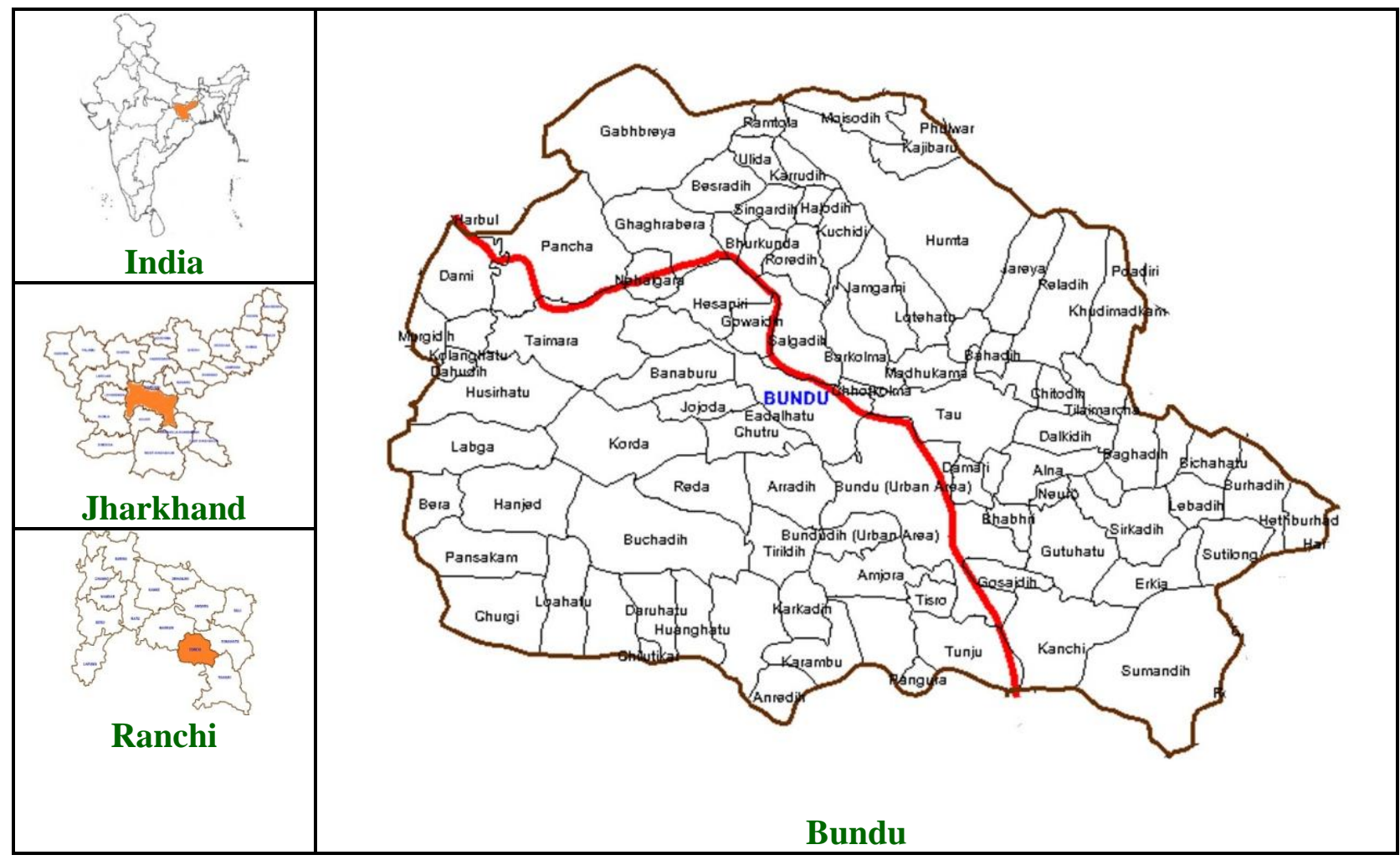

Fig.2 Species composition under different use category

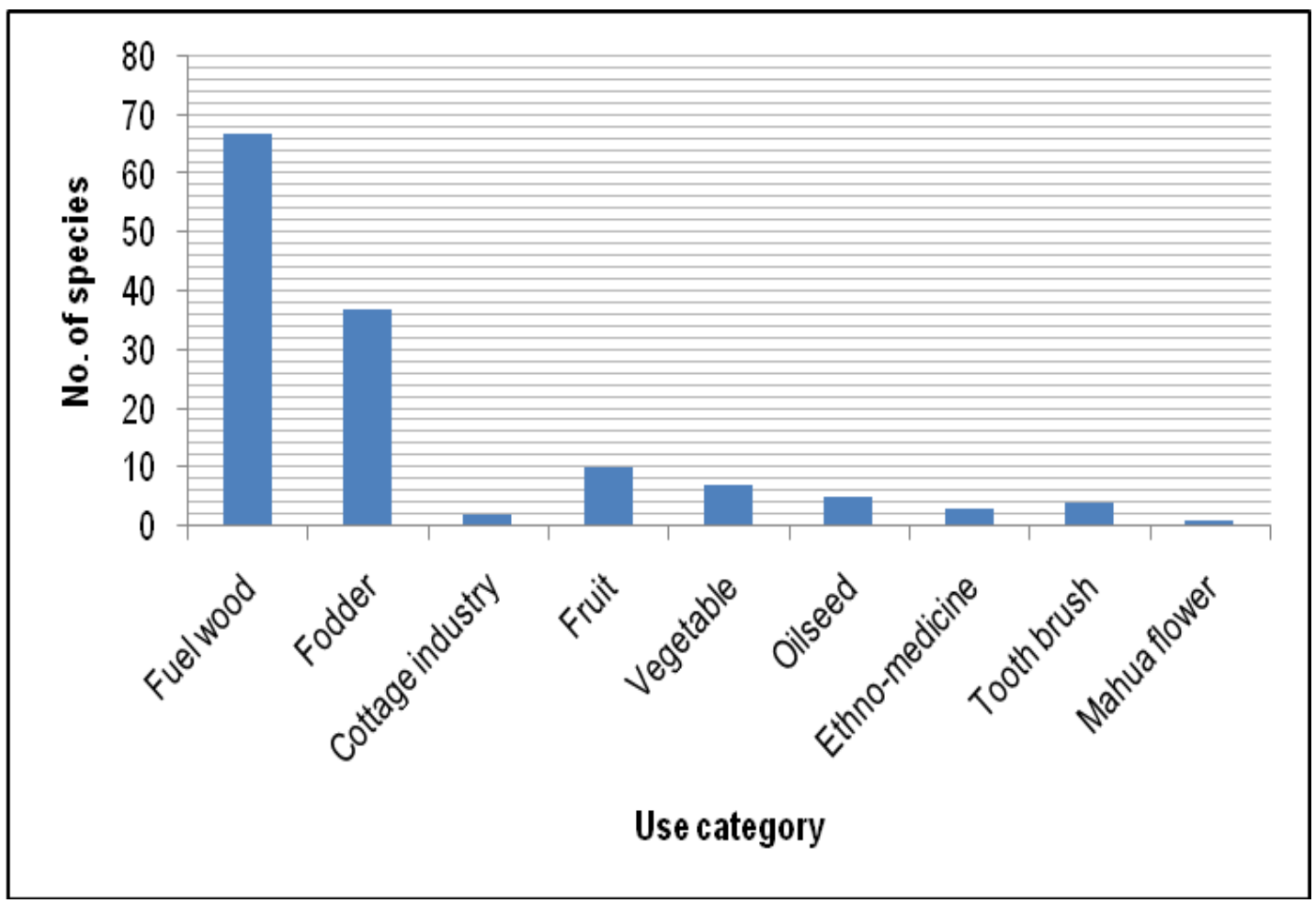


Fig.3 NTFPs based income composition in tribal households

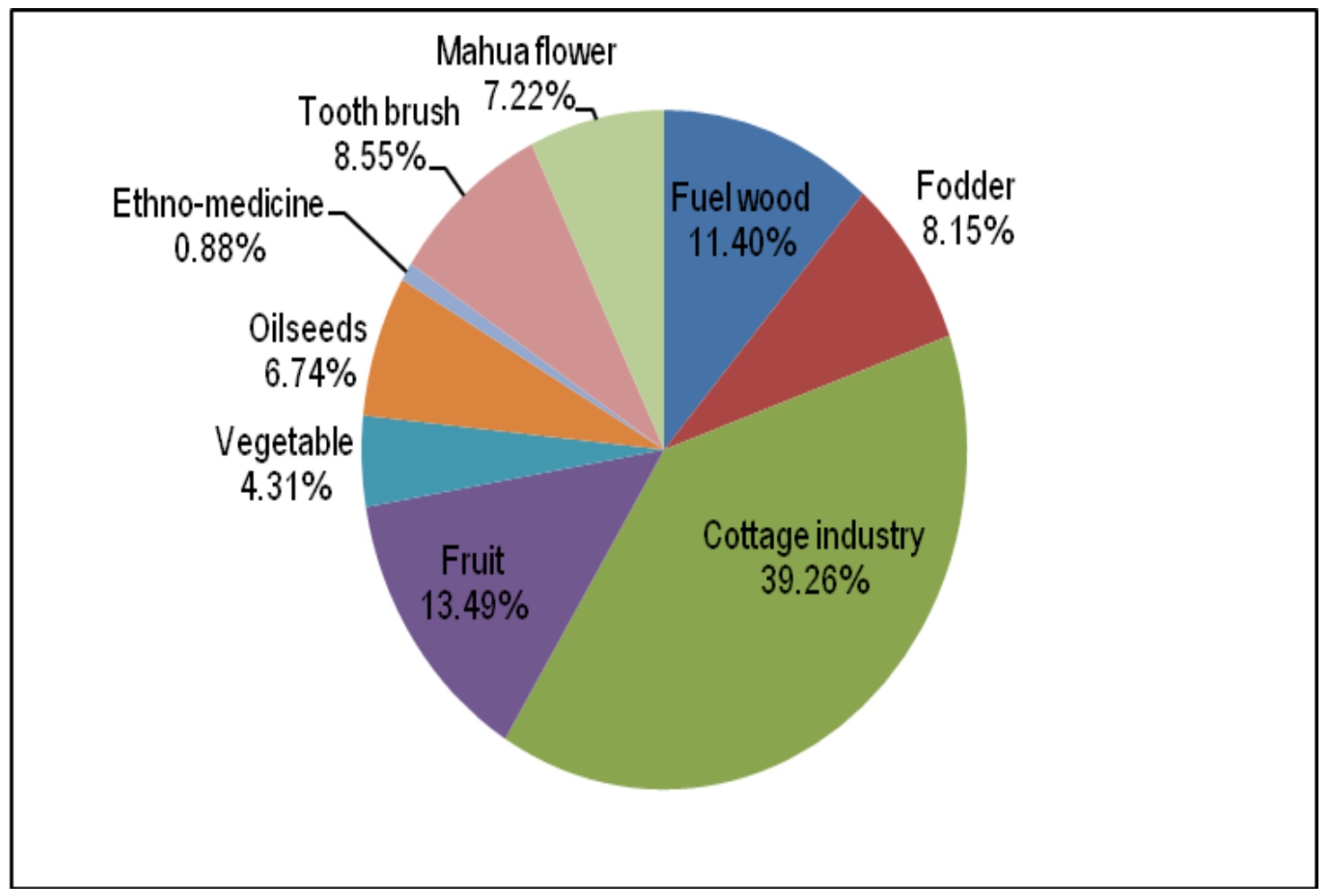

Fig.4 Seasonality of NTFPs extraction in the tribal households

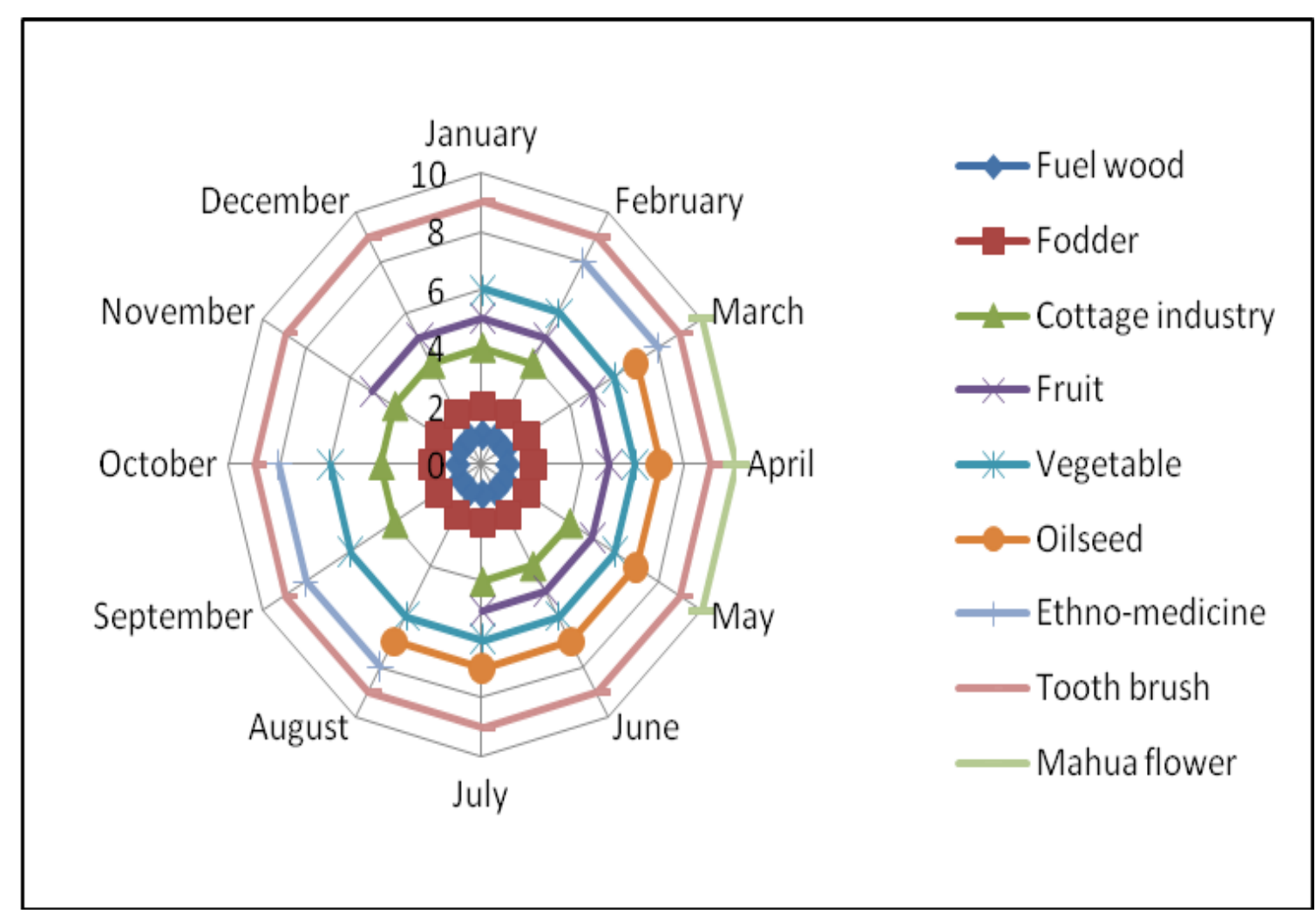


Fig.5 Contribution of NTFPs to the household income (Rs. annum ${ }^{-1}$ )

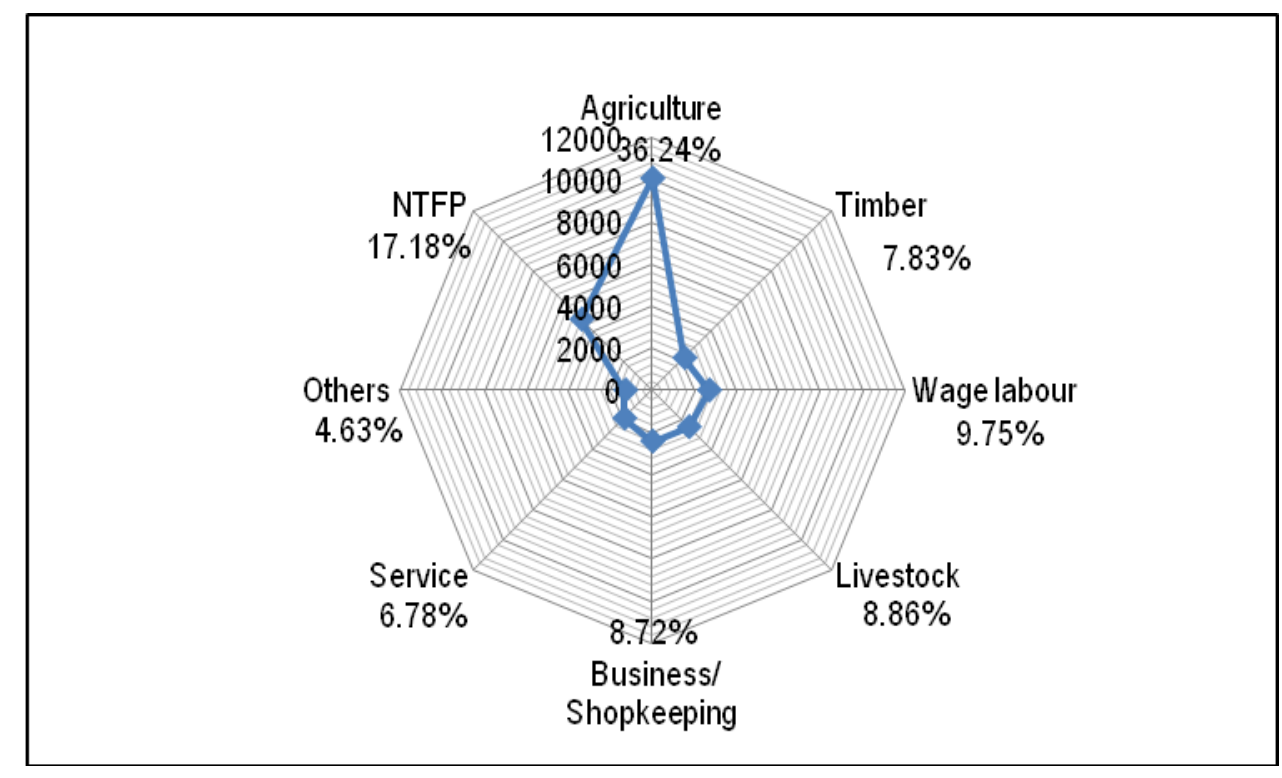

Fruits were the next important income generating NTFPs accounting a considerable share in the NTFPs based annual income. Fruits fulfill the food, health and nutritional needs of tribal communities to a considerable extent, hence, collection and sale of fruits is a promising business among them. Fuel wood collection and sale is a productive economic activity because the fuel wood is the principal source of energy constituting maximum share in total bio-fuels consumption among the tribal households. The collection and marketing of tooth brush, fodder, mahua (Madhuca latifolia) flower, oilseeds, vegetables and ethno-medicine comparatively generated less income for the tribal households due to low unit price or the limited market demand.

\section{Seasonality of NTFPs exploitation}

Seasonality of NTFPs exploitation (Fig. 4.) revealed that fuel wood, fodder and tooth brush are collected and marketed throughout the year while sal leaf plates, lac, fruits and vegetables are sold for 9-10 months by the tribes. Oilseeds and ethno-medicine are vended for 5-6 months whereas mahua
(Madhuca latifolia) flower is traded only for 3 months.

NTFPs have inconsistent abundance according to season and the marketing of these resources differs with the seasonal livelihood avenues of the tribal people. All the main NTFPs are available for around 6 months excluding fuel wood, fodder, sal leaf, lac and tooth brush and peak trade is limited for only 3-4 months. Summer, spring and autumn seasons witness a large quantum of NTFPs influx as against the rainy season, where availability of NTFPs is least. Engagement in agriculture and difficulties in collection and storage of NTFPs causes decline in the quantity of NTFPs in the monsoon. Thus, the NTFPs explicitly provide livelihood support to the tribes throughout the year.

\section{Contribution of NTFPs to the tribal economy}

Average gross income consisted of various on-farm and off-farm sources was Rs. 27894.20 household $^{-1}$ annum $^{-1}$ with a breakup of agriculture (36.24\%), NTFPs (17.18\%), 
wage labour (9.75\%), livestock (8.86\%), business/ shop keeping (8.72\%), timber (7.83\%), service $(6.78 \%)$ and others $(4.63 \%)$ (Fig. 5.). Hence, the NTFPs are the $2^{\text {nd }}$ chief contributor to the total income streams in the tribal households.

NTFPs accord viable livelihood support for subsistence, cash income and safety-net among the tribes due to scarcity of alternative options, small size of land holding for agriculture and marginal agricultural returns (Maske et al., 2011; Langat et al., 2016.). Collection and sale of NTFPs is not a main livelihood source in tribal households but is a supplementary job either on a part-time or full-time basis (Bhatia and Yousuf, 2013; Islam et al., 2016). Households engaged in agriculture and livestock production were consuming more quantity of NTFPs than households not engaged in farming activities. Similarly, the poorer households use greater quantity of NTFPs for earnings than wealthier households. Nonetheless, the income from NTFPs is somewhat little; involvement in the trade is traditional source of self-esteem, pride and sovereignty for the tribes (Usman et al., 2016). Incomes earned from NTFPs are variable across tribal households since it is directly related to the availability of labour force and work force expended. Earnings from the NTFPs are spent to meet household basic needs besides securing other livelihood perspectives like education of children, wedding, marriage, agricultural investment, savings for household vocations, economic buffer in adverse times etc. Studies (Gharai and Chakrabarti, 2009; Singh et al., 2009; Salehi et al., 2010; Sarmah and Arunachalam, 2011; Singh and Quli, 2011; Alex and Vidyasagaran, 2016; Amusa et al., 2017) on NTFPs exploitation advocated that the NTFPs have significant contribution to the total livelihoods in tribal populace.

The foregoing discussion led to conclude that the tribes of the Bundu block exploit diverse
NTFPs substantially to support their livelihoods. Wealthier households exploit the NTFPs on a regular basis and in meaningful quantities for direct household consumption to support agriculture and livestock rearing. The poorer households having limited farms and livestock exploit the NTFPs in large scale for their subsistence, income and safety-net in adverse times. Poverty, immense unemployment and lack of alternative occupations are the major driving forces responsible for the over-exploitation of NTFPs. This study deduces the fact that the tribal livelihood was by and large dependent on the status of the NTFPs, underlining the relevance of forest conservation for improvement of tribal livelihoods on sustainable basis. The encouraging support of goods from NTFPs to the tribal households can be used as a key motivational factor for securing the highly demanded large scale afforestation and reforestation on participatory basis, to achieve the targets of greening India mission, which in turn would back up the greening the earth mission. The gainful inference of this proto-type study would rapidly spread far and wide for endorsement of the global mission of Reducing Emissions from Forest Degradation and Deforestations $\left(\mathrm{REDD}^{+}\right)$from developing countries for Clean Development Mechanism (CDM) as envisaged by Kyoto Protocol of IPCC, 2007. Further this would also facilitate in achieving the poverty eradication and environmental sustainability targets of the United Nation's Millennium Development Goals (MDGs). The exploration reflected the high potentials of NTFPs for prosperity of the tribes which needs to be mobilized effectively to curb the deleterious extremist activities and migration from the rural areas.

\section{Acknowledgement}

Authors acknowledge their heartfelt indebtedness for the valuable cooperation of the Gram Pradhans, clan heads, local leaders, 
Government officials and NGO workers in carrying out this research work. The respondents deserve special applaud for their honest data and knowledge sharing, which formed the basis of this work.

\section{References}

Ahenkan, A. and Boon, E. 2011. Non-timber forest products (NTFPs): Clearing the confusion in semantics. Journal of Human Ecology, 33(1): 1-9.

Ajake, A.O. and Enang, E.E. 2012. Demographic and socio-economic attributes affecting forest ecosystem exploitation and management in the rural communities of cross river state, Nigeria. American International Journal of Contemporary Research, 2(1): 174-184.

Alex, A. and Vidyasagaran, K. 2016. The marketing of non-timber forest products in the Western Ghats region of Attappady, Kerala. Economic Affairs, 61(3): 355-363.

Amusa, T.O., Jimoh, S.O. and Azeez, I.O. 2017. Socio-economic factors influencing marketing of non-timber forest products in tropical lowland rainforests of south-western Nigeria. Southern Forests: a Journal of Forest Science, 2017: 1-8.

Anon., 2009. State of Jharkhand - Overview. Retrieved from http://jharenvis.nic.in.

Bedia, S. 2014. Study on the forest based livelihood for the selected tribal population of Ranchi district of Jharkhand. B.Sc. Dissertation, Unpublished. Faculty Centre for Integrated Rural and Tribal Development and Management, School of Agriculture and Rural Development. Ranchi, India.

Bharathkumar, L.B., Patil, B.L., Basavaraja, H., $\quad$ Mundinamani, S.M., Mahajanashetty, S.B. and Megeri, S.N.
2011. Participation behaviour of indigenous people in non-timber forest products extraction in Western Ghats forests. Karnataka Journal of Agricultural Sciences, 24(2): 170-172.

Bhatia, N.K. and Yousuf, M. 2013. Reassuring livelihood functions of the forests to their dependents: Adoption of collaborative forest management system over joint forest management regime in India. Annals of Forestry Research, 56(2): 377-388.

Census of India, 2011. A - 5 State Primary Census Abstract - 2011, Government of India.

Chamberlain, J.L., Bush, R., Hammett, A.L. and Araman, P.A. 2000. Managing national forests of the eastern United States for non-timber forest products. In: B Krishnapillay GIVE MORE NAMES et al., (Eds.): Forest and Society: The Role of Research. Subplenary Sessions. XXIIUFRO World Congress 2000. Kuala Lumpur, Malaysia. Vol. 1: 407-420.

Champion, H.G. and Seth, S.K. 1968. Revised survey of forest types in India. Manager of Publication, FRI Press, Dehra Dun, India.

Gharai, A.K. and Chakrabarti, S. 2009. A study on NTFP-related livelihood dependency and people's perception of the commercialization potential of selected NTFP $\mathrm{s}$ in selected locations of Gumla, Hazaribagh \& Simdega districts of Jharkhand, Centre for People's Forestry, Hyderabad.

Ghosal, S. 2011. Importance of non-timber forest products in native household economy. Journal of Geography and Regional Planning, 4(3): 159-168.

IPCC, 2007. Impacts, Adaptation and Vulnerability. Contribution of Working Group II to the Fourth Assessment Report of the Intergovernmental Panel on Climate Change [Parry, M.L., O.F. 
Canziani, J.P. Palutikof, P.J. van der Linden, C.E. Hanson (eds.)]. Cambridge University Press, Cambridge, United Kingdom and New York, NY, USA.

Islam, M.A., and Quli, S.M.S. 2015. Forest resources use for building livelihood resilience in ethnic communities of Jharkhand. Trends in Biosciences, 8(5): 1256-1264.

Islam, M.A., Quli, S.M.S. and Baba, M.Y. 2016. Household drivers of forest dependence for employment support among tribes of Jharkhand, India. Economic Affairs, 61(2): 339-347.

Islam, M.A. Quli, S.M.S., Rai, R. and Sofi, P.A. 2013. Livelihood contributions of forest resources to the tribal communities of Jharkhand. Indian Journal of Fundamental and Applied Life Sciences, 3(2): 131-144.

Islam, M.A., Quli, S.M.S., Sofi, P.A., Bhat, G.M. and Malik, A.R. 2015. Livelihood dependency of indigenous people on forest in Jharkhand, India. Vegetos, 28(3): 106-118.

Langat, D.K., Maranga, E.K., Aboud, A.A. and Cheboiwo, J.K. 2016. Role of forest resources to local livelihoods: The case of East Mau forest ecosystem, Kenya. International Journal of Forestry Research, Vol. 2016: 12-21.

Maske, M., Mungole, A., Kamble, R., Chaturvedi, A. and Chaturvedi, A. 2011. Impact of non-timber forest produces (NTFPs) on rural tribes' economy in Gondia district of Maharashtra, India. Achieves of Applied Science Research, 3(30): 109-114.

Melaku, E., Ewnetu, Z. and Teketay, D. 2014. Non-timber forest products and household incomes in Bonga forest area, south-western Ethiopia. Journal of Forest Research, 25(1): 215-223.

Mukherjee, N. 1993. Participatory Rural Appraisal. Methodology and Applications, Concept
Nayak, B.P., Kohli, P. and Sharma, J.V. 2014. Livelihood of local communities and forest degradation in India: Issues for REDD+. Tata Energy and Resources Institute (TERI), New Delhi, India.

Olaniyi, O.A., Akintonde, J.O. and Adetumbi, S.I. 2013. Contribution of non-timber forest products to household food security among rural women in Iseyin local government area of Oyo state, Nigeria. Research on Humanities and Social Sciences, 3(7): 41-50.

Opaluwa, H.I., Onuche, U. and Sale, F.A. 2011. Factors affecting the collection and utilization of non- timber forest products in rural communities of North Central Nigeria. Journal of Agriculture and Food Technology, 1(5): 47-49.

Prasad, N. and Siddiqui, M.H. 2006. Promotion and protection of Jharkhand forests to mitigate problem of livelihood. My Forest, 42(4): 405-409.

Ray, G.L. and Mondol, S. 2004. Research methods in social sciences and extension education. Kalyani Publishers, New Delhi, India.

Saha, D. and Sundriyal, R.C. 2012. Utilization of non-timber forest products in humid tropics: Implications for management and livelihood. Forest Policy and Economics, 14: 28-40.

Salehi, A., Karltun, L.C., Söderberg, U. and Eriksson, L.O. 2010. Livelihood dependency on woodland resources in southern Zagros, Iran. Caspian Journal of Environmental Sciences, 8(2): 181194.

Sarmah, R. and Arunachalam, A. 2011. Contribution of non-timber forest products (NTFPs) to livelihood economy of people living in forest fringes in Changlang district of Arunachal Pradesh, India. Indian Journal of Fundamental and Applied Life Sciences, 1(2): 157-169.

Shackleton, C.M. and Pandey, A.K. 2014. 
Positioning non-timber forest products on the development agenda. Forest Policy and Economics, 38: 1-7.

Sharma, D., Tiwari, B.K., Chaturvedi, S.S. and Diengdoh, E. 2015. Status, utilization and economic valuation of non-timber forest products of Arunachal Pradesh, India. Journal of Forest and Environmental Science, 31(1): 24-37.

Shit, P.K. and Pati, C.K. 2012. Non-timber forest products for livelihood security of tribal communities: A Case Study in Paschim Medinipur District, West Bengal. Journal of Human Ecology, 40(2): 149-156.

Shrey, R., Choudhary, V.K. and Dhurwey, C.K. 2017. Economic Impact of Non Timber Forest Products on Tribes of Chhattisgarh. Indian Journal of Economics and Development, 13(2): 2331.

Singh, P.K. and Quli, S.M.S. 2011. Economic valuation of non-timber forest products contribution in tribal livelihood in West
Singhbhum district of Jharkhand. The Indian Forester, 137(11): 1258-1264.

Singh, P.K., Quli, S.M.S. and Kerketta, J. 2009. Economic potentiality of community based forest (Mundari Khutkatti) management: A case study of an Indian tribal region. Jharkhand Journal of Development and Management Studies, 7(4): 3659-3668.

Snedecor, G. and Cochran, W.G. 1967. Statistical methods. Iowa State University Press, Ames, Iowa, USA.

Tewari, D.D. 2014. Is big business approach to managing non-timber forest Products (NTFPs) benign? Rising unsustainable extraction and looming policy challenges. Journal of Human Ecology, 47(1): 87-102.

Usman, Y., Danjuma, M.N. and Abdulkarim, I.A. 2016. Roles of forest resources in sustaining rural livelihoods around Yankari Game Reserve, Nigeria. Pyrex Journal of Geography and Regional Planning, 2(1): 11-15.

\section{How to cite this article:}

Islam, M.A. and Quli, S.M.S. 2017. The Role of Non-Timber Forest Products (NTFPs) in Tribal Economy of Jharkhand, India. Int.J.Curr.Microbiol.App.Sci. 6(10): 2184-2195. doi: https://doi.org/10.20546/ijcmas.2017.610.259 